\title{
Turkish municipalities: Reconsidering local democracy beyond administrative autonomy
}

\section{S. Ulaş Bayraktar}

\section{OpenEdition}

\section{Journals}

Édition électronique

URL : http://journals.openedition.org/ejts/1103

DOI : 10.4000/ejts. 1103

ISSN : 1773-0546

Éditeur

EJTS

Référence électronique

S. Ulaş Bayraktar, «Turkish municipalities: Reconsidering local democracy beyond administrative autonomy », European Journal of Turkish Studies [En ligne], Liste complète, mis en ligne le 08 octobre 2007, consulté le 19 février 2020. URL : http://journals.openedition.org/ejts/1103 ; DOI : 10.4000/ejts. 1103 


\title{
ejtS.orgeteuropean journal of turkish studies
}

Citation: Bayraktar, S. Ulaş (2007) 'Turkish municipalities: Reconsidering local democracy beyond administrative autonomy', European Journal of Turkish Studies, Articles, URL : http://www.ejts.org/document1103.html To quote a passage, use paragraph $(\S)$.

\section{Turkish municipalities: \\ Reconsidering local democracy beyond administrative autonomy}

\author{
S. Ulaş Bayraktar
}

\begin{abstract}
Within Turkish political science literature, local democracy has been mainly perceived as an administrative issue defined in the narrow framework of administrative and financial autonomy and simplified in a general dichotomy with the central government. Yet, since the eighties, Turkish municipal framework has undergone very significant administrative, financial and functional changes, albeit without bringing about a veritable democratisation of local politics. As a matter of fact, the popular understanding of local democracy in Turkey does not really deal with infralocal democratic issues such as the problems of power distribution, of political representation and participation. Thus, a different understanding of local democracy beyond dimensions of administrative tutelage, financial resources and functional limits is required. Departing from this observation, I argue that a new conceptualisation of local democracy including more political elements is required to understand the contemporary state of Turkish local politics. This paper intends to be a preliminary step for reaching such a new understanding of local democracy for the Turkish context.
\end{abstract}


Turkish political science literature in which problems of democracy and democratisation have been one of the most popular research issues, local democracy remained quite neglected ${ }^{1}$. The notion of 'local democracy' appeared mainly as an item of political discourses and propagandas except for a few works in which it generally indicated an enhanced autonomy for local governments 2 . Subjected to a strong administrative tutelage as well as very limited economic resources and expected just to provide basic public services, local governments are believed to suffer significantly from the centralist state tradition. As İncioğlu (2002: 75) puts:

[2] 'Historically, the Turkish administrative system has had a strong centralist orientation that reflected the relative weakness of local institutions vis-à-vis the state. Burdened with the excessive and financial controls exercised over them by the central resources, municipalities remained weak and dependent on Ankara.'

[3] In such an administrative tradition, local democracy has been naturally perceived in direct reference to the central government and thus corresponded roughly to the administrative and financial autonomy of local governments, particularly that of municipalities. Trapped on such a narrow stage, the enhancement of local democracy was reduced to an isolated power struggle between the central and local players in which citizens have no significant role to play.

[4] For instance, in one of the few works dealing specifically with local democracy, Görmez (1997: 144) discusses the evolution of Turkish municipal framework from a democratic perspective. Even if he defines local democracy as the effective participation of citizens directly or indirectly to the decision-making processes, in the study, the notion appears usually as a quasi synonym of local autonomy. Thus, author's discussion on Turkish local democracy follows mainly the changes about financial resources, legal competencies as well as functions of and administrative tutelage over Turkish local governments. In such an approach, even the law on expropriation by municipalities appears as an issue of local democracy (1997: 115). Consequently, author interprets the rights on urban plans as well as the new financial resources that the municipalities acquired in the 1980s as very significant steps towards local democracy (1997: 146-150).

\footnotetext{
${ }^{1}$ I would like to thank Ali Ekber Doğan and Bediz Yılmaz as well as two anonymous referees for their enriching remarks and suggestions to the preliminary versions of this paper.

2 'The main philosophy behind the idea of autonomous local governments is the self-government of the people. Thus, autonomy is the product of the idea of democratic government. Indeed, local autonomy is the democracy itself' (Yüksel 2005: 276). More original (!) approaches can be of course noted: 'Democracy at the local level provides the instruments required for enhancing local democracy...' (Öner 2005: 58).
} 
[5] In this paper, I shall yet try to illustrate how outdated this reading of local democracy is in the light of how Turkish municipal universe has evolved since $1980^{3}$. Enjoying a greater autonomy and enhanced financial resources as well as carrying out very important socio-economic functions, Turkish municipalities are no longer simple subjects of the central government. Nevertheless, this improved status of municipal bodies has not actually resolved the problematic of Turkish local democracy if a different understanding of the concept simply beyond dimensions of administrative tutelage, financial resources and functional limits is adopted. As a matter of fact, the popular understanding of local democracy in Turkey does not quite deal with infra-local democratic issues such as the problems of power distribution, representation and participation. Therefore, a different conceptualisation of local democracy including more political elements is required for understanding the contemporary state of Turkish local politics. This paper intends to be a preliminary step for reaching such a new understanding of local democracy for the Turkish context.

[6] For this purpose, I shall first present an overview of the historical development of the Turkish municipal system in order to illustrate the chronicle bottlenecks of Turkish local democracy according to the traditional reading of the notion. Then, changes in these aspects of the municipal system that have occurred since the 1980s up until the recent reform will be mentioned to see whether these changes have brought about a democratic impact on local politics or not. In the final section, I shall deal with more political dimensions of the Turkish municipal universe with the aim of providing new conceptual elements for a new definition of local democracy.

\section{Historical synopsis of the Turkish municipal system}

\section{Exceptional autonomy of the first constitutional framework}

[7] The foundation of the Turkish Republic in October 1923, followed by the victory of the Independence War in 1922, was accomplished owing to a wide cooperation of central elites, local notables and ordinary countrymen. As a result of this grand coalition, the principle of populism

${ }^{3}$ I would like to particularly emphasize that within this paper, I deal only with the municipal dimension of Turkish local governmental system. The provincial administration that did not dispose any significant functions and competencies until the recent reform will be deliberately left out of my discussion. 
Citation: Bayraktar, S. Ulaş (2007) 'Turkish municipalities: Reconsidering local democracy beyond administrative autonomy', European Journal of Turkish Studies, Articles, URL : http://www.ejts.org/document1103.html To quote a passage, use paragraph $(\S)$

appeared to be the main motto of the movement as seen in Mustafa Kemal's early discourses upon his arrival in Ankara in December 1919:

[8] 'Within our organisation... the national paramount... every individual must become personally concerned with his destiny. A structure that in this way rises from below to the top, from the foundation to the roof, will surely be sturdy... I have been gratified to observe that our national organisation... has reached down to its true point of origin, to the individual, and that from there the real structuring upward has also begun' (quoted by Rustow 1991: 12).

[9] This principle of populism that valorised the grassroots is also reflected in the priority attributed to local governments. Indeed, more than half of the articles of the first constitutional framework of the post-ottoman period were on the local organisations (13 out of 23). In the light of this legislation, the country was divided into departments (vilayet), towns (kaza) and villages (nahiye) (art. 10). Departments and villages possessed public identities, enjoyed administrative autonomy and were governed through local councils that were responsible for organising and administrating public services related to local foundations, religious or secular schools, health, economy, agriculture, public works and charity (art. 11). Councils were elected for two years and chose their own president and an executive committee from among themselves (art. 12 and 13). Prefects appointed by the centre were responsible only for the national government affairs. Therefore, this first law on local governments represented indeed a very significant move towards a democratic organisation of local politics. As Ortaylı states, this legal structure was a 'unique status that can be matched neither in the past nor in present, envisaging the development of local governments and democracy in Turkey... There is no doubt that this status is a noteworthy period of our [Turkey's] democratic history' (quoted by Güler 1998: 154).

[10] This democratic exception with regards to local governments was probably possible thanks to the considerable presence of local notables in the first Assembly. Among the 365 deputies of this legislative body, there were 129 landlords and/or merchants, 53 religious and 5 tribe leaders who would be shortly left out by the second elections in 1923 (ibid.) since they did not appear to be eager in supporting a revolutionary modernisation project. For them, the basic objective of the collective upheaval against the foreign invaders was to save the Empire, hence the Sultan who was believed to be captured by enemy forces, and the religion, which was threatened by the infidels. Therefore, when contributing to the national resistance, local notables did not have the intention of transforming the traditional political system entirely. The second Assembly freed from these 
Citation: Bayraktar, S. Ulaş (2007) 'Turkish municipalities: Reconsidering local democracy beyond administrative autonomy', European Journal of Turkish Studies, Articles, URL : http://www.ejts.org/document1103.html To quote a passage, use paragraph $(\S)$

unenthusiastic members with regards to a modernising process, represented a perfect continuity with the character of ruling elites of the Imperial past. Bureaucrats and officers of the previous regime reacquired their power within the political system; more precisely $93 \%$ of the high officers and $85 \%$ of bureaucrats of the Ottoman Empire continued to serve for the Republic (Özbudun 1995: 7-8).

[11] The stability with regards to the ruling elite between the imperial and republican periods was also a sign of the continuation of reform ideas and modernisation projects of the late Ottoman period. The supporters of political and social reforms were now definitively in power and were able to pursue their ideals more effectively since the counter-power of the Sultan had disappeared. Centralist tendencies were ready to re-appear on the political scene.

[12] The main characteristic of the modernisation project was the westernisation of institutions and of social features of the Republic. However, society did not seem to be quite encouraging these reform projects. Nevertheless, the hesitation of society towards the reforms was not enough for discouraging the ruling elite from carrying on their modernisation project. However, in light of the lack of popular enthusiasm for such reforms, the principle of populism seemed to become a goal per se rather than an effective instrument to govern; that is to say, the bottom-up structure of government turned out to be seen 'as an end in itself rather than a means for achieving some higher order' (Turan, 1993: 131). Mustafa Kemal justifies this change in the character of the populism principle by stating that 'there is a need at the beginning of any undertaking, to go not from below upwards but from above downwards' (quoted by Rustow 1991: 13).

[13] In this perspective, society was not able to distinguish its real interests and needs, due to the fact of being subjected for centuries to the absolute authority of Sultans. Given this indifference of the society towards the republican ideals, the first duty of the governing bodies was seen to be the achievement of a cultural modernisation by the realisation of some radical reforms, such as the reform of clothing, of alphabet etc. and by the establishment of some local institutions (The People's Houses/ Rooms) in order to mobilize and train people. Their official description of these efforts was 'to safeguard the citizen from the ill effects of old traditions' (quoted by Karpat 1991: 52).

[14] Given such scepticism towards society, the maintenance of the local autonomy attributed to local governments with the Constitution of 1921 would be quite paradoxical. Indeed, very shortly after the approval of the new constitution, a new legislation concerning the local governments was launched. The initial idea was to prepare separate laws for each administration level (from villages to 
Citation: Bayraktar, S. Ulaş (2007) 'Turkish municipalities: Reconsidering local democracy beyond administrative autonomy', European Journal of Turkish Studies, Articles, URL : http://www.ejts.org/document1103.html To quote a passage, use paragraph $(\S)$

metropolitan municipalities) starting with the villages. Indeed, the Law on Villages was accepted in 1924. However, later on, this idea of separate legislation was renounced and a universal municipal law was prepared in 1930.

\section{The new municipal structuring under contradicting dynamics}

[15] The political content of the municipal law No. 1580, to remain in force for 75 years, was determined by two contradictory forces: the importance of local autonomy and the need for central supervision. The report of the mixed commission responsible for the preparation of the law perfectly demonstrates this contradiction:

[16] 'Experience gained over half a century has proven that, be it in Istanbul or other districts, municipal government needs to be strengthened; in order to rescue our communes from their miserable and ruined condition, it is socially and economically essential to upgrade the powers of municipalities to the level that they are found in developed countries. Yet, in acknowledging this requirement, we should not disregard another socio-political obligation, namely that of keeping these governments under the supervision of the state. The possibility of anarchy at state government level can be prevented only if central supervision is enhanced in parallel with the extended powers of municipalities' (quoted by Aytaç 1990: 91).

[17] Evolving under such contradictory concerns, the law brought into being a municipal framework that was perceived mainly as an extension of the central government's responsibility for carrying out local public services. The ban on deciding political issues in the municipal council would be the best evidence of the emphasis on the public service delivery function of municipalities (Mumcu, Ünlü 1990: 116). This service-based nature of Turkish municipalism can be better seen by referring to the functions allocated to the municipalities. As a matter of fact, article 15 of the law allocates 76 different duties to the municipalities in areas such as urban infrastructure, basic urban services, town planning and controls, the provision and the control of clean food, health and some religious services, cultural activities, housing and social aid facilities etc.

[18] The depoliticisation of local governments was also related to two of the major political principles of the Kemalist regime, namely populism and statism (Mumcu, Ünlü 1990: 113). The substitution of the initial eulogy of 'national sovereignty' by a Jacobinic populism summed up as 'For the people, despite the people' required a total control of local society, especially of local power brokers who were mainly excluded from the national scene by the second parliamentary elections. By 
Citation: Bayraktar, S. Ulaş (2007) 'Turkish municipalities: Reconsidering local democracy beyond administrative autonomy', European Journal of Turkish Studies, Articles, URL : http://www.ejts.org/document1103.html To quote a passage, use paragraph $(\S)$

minimizing the political power of municipalities, the Kemalist regime aimed to prevent the traditional provincial power figures from acquiring public power. In doing so, any deviation from the Kemalist modernisation project would be prevented. Local affairs were thus either supervised directly from the capital or carried out by provincial governments presided by the prefect (Güler 1998: 155) ${ }^{4}$.

[19] The second Kemalist principle that led to the depoliticisation of municipalities was the emphasis on statist policies. Local public resources were obliged to be used in large-scale public investments either for industrial development or for building/improving transport and communication infrastructure in the most urbanized parts of the country. Consequently, the financial power of local governments was minimized; local public resources were transferred either to the central government or to other more privileged cities, and the planning, funding and carrying out of local public works schemes were undertaken by central institutions such as the Bank of Municipalities (Belediyeler Bankası) or the Board of Municipal Public Works (Belediyeler Imar Heyeti) (Güler 1998: 159-160).

[20] In short, the municipal framework was designed as an instrument of the national modernisation process. In order to minimize local elite's reactionary influence in national politics, local governments were depoliticized. Besides, local public resources and works were placed under the strict control of central government, so that they could be efficiently used for the general socioeconomic development of the country rather than for the specific needs of localities.

\section{Mono-partite environment despite the transition to a multi-partite regime}

[21] Turkish local politics was thus not only instrumentalised by the centralist state tradition but also manipulated by the local interest groups. However despite this subjected state of local politics, local democracy did not appear as a significant political issue until the seventies simply because the party holding the power at the national level also controlled local governments.

\footnotetext{
${ }^{4}$ Yet, the actual outcome of these policies turned out to be quite contrary to the initial objectives. The isolation of local elite from the national political scene did not in fact prevent their political strengthening at the local level. On the contrary, as a payback, they were left on their own in local politics that let them benefit from the limited -yet not insignificantresources and competencies of local governments. Especially, merchants and entrepreneurs who were organized under professional chambers became very influential in municipal organs. Moreover, the significant acceleration of massive rural exodus after the Second World War weakened the republican elitism of the centre since the grand cities like Istanbul, Ankara and Izmir that were identified with the republican ideals, were henceforth the hometown of hitherto rural populations. In the absence of adequate public policies to meet their urgent needs, the new residents of these big cities, built up their own informal solidarity networks and patronage channels that further strengthened initially excluded local political elite. Thanks to these two factors, the local power-holders gradually enhanced their influence in national politics.
} 
Citation: Bayraktar, S. Ulaş (2007) 'Turkish municipalities: Reconsidering local democracy beyond administrative autonomy', European Journal of Turkish Studies, Articles, URL : http://www.ejts.org/document1103.html To quote a passage, use paragraph $(\S)$

Consequently, municipalities were subjected not only to an administrative tutelage but also to political pressures through partisan relationships. In other words, although the political system was reformed in order to allow diverse political formations ${ }^{5}$, de facto practices of mono-partitism were maintained. Even in those exceptional cases where the ruling Democrat Party (DP) lost the municipality, democratic principles were degenerated in order to secure the influence of central government over local governments. What took place in Malatya in the very early period of DP's rule is quite illustrating how the opposition suffered from this mono-partite political culture.

[22] The incident broke out when the elected mayor of Malatya refused to take down the portrait of ex-president of the Republic İsmet İnonu6 from the walls of the mayor's office despite prefect's word of warning that he would then solicit the Ministry of Interior for mayor's dismissal. In the justification for his demand, the prefect claimed that the municipality had tried to give an impression of disposing an autonomous authority by refusing the prefect's request. However, according to the legislation on municipalities, such a claim could be actually made if only the mayor refused to execute his official functions despite prefect's written demand; taking down a picture from the wall was not obviously among the official functions of the mayor.

[23] The government insisted on the dismissal of the mayor regardless of administrative court's and Council of State's adverse decisions. The justification of the government's illegal act was extremely evocative with regards to DP's approach to local governments since the declaration was qualifying municipalities and mayors as agents of the central government. In any case, according to the government, even the municipal autonomy did not bring about a right to ignore the decisions and the demands of public authorities. Such an autonomy would be possible if the localities had disposed the right of self-governing which would be only possible in federal states; it was obviously not the case. As a matter of fact, after the dismissal of the mayor, the central government dissolved the municipal council that decided to keep the portrait on the wall. The dissolution was justified by considering the council's decision as a political act (Geray, 1990: 219).

\footnotetext{
${ }^{5}$ From the foundation of the Republic, until the formal transition to a multi-partite regime in 1945, Republican People's Party (CHP) was the only political organization of the country, excepted two unsuccessful essays of multi-partitism (in 1924 and 1930). The first Turkish elections with an actual opposing party were realized in July 1946, albeit with numerous claims about electoral frauds and bureaucratic repression on behalf of the governing CHP. Yet, four years later in 1950, it could obtain only 39 seats in the Assembly whereas 408 seats were lost to DP that was founded as rather safety valve (Ahmad 1993: 105) from among the ex-members of CHP.

6 Inönü was the unquestioned successor of Atatürk and thus 'the second man' of the Republic. He kept his political influence in the country until the 1970s by presiding CHP all through this period. Malatya was his hometown.
} 
[24] The 'portrait' incident of Malatya illustrated clearly that the municipalities were still considered an organic extension of the central government even after the transition to a multi-partite regime. Any tension between the two levels of government revealed how fragile the formal autonomies of local governments were. Examples of such incidents of grave central-local tension can not be multiplied simply because DP won the mayoralty of 560 municipalities out of 600 in the local elections of September 1950. In other words, four years after formal transition to multi-partitism, Turkey returned to a de facto mono-partitism since DP believed to dispose an unlimited legitimacy issued from their electoral victories that rendered the Party totally free to undertake whatever they would like. Henceforth, unlike the mono-partite period, there was in fact a party of opposition yet without any right to intervene in the government of the country. Not surprisingly, local governments were far from being considered as autonomous political bodies that could independently deliberate, decide and execute local policies.

[25] The maintenance of the mono-partite political culture was not in fact restricted to the relationship between central and local governments and affected the totality of the political sphere. Restrictions on the political opposition, the consideration of all state institutions being at the service of the party and the belief of having the right of exercising political power without any restraint paved gradually the way to the first military intervention of the republican era on May $27^{\text {th }}, 1960$.

\section{Persisting municipal weakness despite a liberal constitution}

[26] The new constitution established by the junta in 1961 was in fact the most liberal constitution of the Turkish Republic and represented the outcome of an important scepticism with regards to political actors. New institutions were introduced in order to prevent the arbitrary, undemocratic and unconstitutional acts of governments: The Grand National Assembly became bicameral with the creation of a Senate; the Constitutional Court was founded to review the constitutionality of the legislation; the electoral system was modified according to proportional representation and the autonomy of certain public institutions such as universities or public broadcasting was strengthened. In addition to these institutional changes, all civil liberties, including freedom of thought, expression, association and publication were guaranteed by the new constitution. 
Citation: Bayraktar, S. Ulaş (2007) 'Turkish municipalities: Reconsidering local democracy beyond administrative autonomy', European Journal of Turkish Studies, Articles, URL : http://www.ejts.org/document1103.html To quote a passage, use paragraph $(\S)$

[27] Despite such fundamental changes in the constitutional framework, the local governmental system was not actually amended. Even if the principle of decentralisation was formally evoked in the new constitution by the explicit separation of central and local governments (art. 112) and the requirement of allocating adequate resources to the latter (art. 116), the old system was in reality maintained due to the lack of laws that would translate these constitutional principles into actual practices. The only major differences with the past were on the supervision of municipalities and the election of the mayors. Henceforth, the inspection of municipalities would be carried out only by judicial mechanisms and thus not by the agents of the central government and mayors would be elected directly by the citizens (law $n^{\circ} 307$ approved in 1963).

[28] Apart from these minor changes ${ }^{7}$ in the legal framework, the financial and political problems of the municipalities persisted. The centralist pressures were even accentuated with the transition to a planned economy in the 1960s. Following the Keynesian economic principles favouring the development of a welfare state, the new regime was inclined to centralise decisions, functions and resources in order to enable the application of macro socioeconomic plans. For instance, the share of local governments in the total public revenues decreased from $16.35 \%$ in 1960 to $5.67 \%$ in 1972 representing a reduction of $42 \%$ in the municipal service production per capita (Altaban 1990: 319). Furthermore, the Law $n^{\circ} 6785$ transferred the competencies related to public works and urbanism to the central government. Accordingly, the decentralisation principles of the new constitution were not respected; the municipal autonomies were forgone for a rapid socioeconomic progress; the financial and administrative dependence of the municipalities on the central governments was thus accentuated. The continuity of centralist pressures on local governments was actually quite strange for the political atmosphere of the country which was identified -at least at the beginning- with a general liberalisation and pluralisation of politics.

\footnotetext{
7 When its eventual outcomes that I shall discuss later on are considered, the new electoral system of mayors appears to represent perhaps more than a minor change. As a matter of fact, Turkish experience of more then four decades on directly-elected mayors need to be further examined at a time when strengthening of local executives and direct election of mayors are gaining ground throughout Europe from Germany to Italy ; from Britain to Norway. For a comparative study of such reforms see Rao and Berg (2006).
} 


\section{The 'new municipalism' of the seventies}

[29] In 1973, for the first time, social democrats in opposition managed to control the largest Turkish cities such as Istanbul, Ankara and Izmir. This would be also the first example of a cohabitation between the central and local governments since until then the same political party generally held the power in both levels. Responding to this local 'dissidence', the central government further restricted the financial autonomy of municipalities on the one hand and made an excessive use of its right of administrative tutelage on the other. The political autonomy of municipalities, the need for administrative decentralisation as well as the question of local democracy, were finally on the political agenda of the country. The reaction of the social democrat mayors against this centralist repression was to initiate a national municipal movement that would be later called as the 'New Municipalism'. The new municipality defined by the movement would be: democratic and participatory; productive; fund-raiser; advisor; organizer; and unionist.

[30] The 'New Municipalism' based on these six principles was born as a pure initiative of several mayors. The local actors, until then dependent on the central resources and policies, were henceforth claiming their political autonomy vis-à-vis the central government. Furthermore, the hostility of the latter to this demand led them develop innovative strategies in fund raising and in intermunicipal cooperation. Besides, thanks to a concern of internal democratisation of the municipalities, considerable efforts were displayed to associate citizens to the government of their localities. Nevertheless, despite the sincere willingness of reaching citizens, the movement did not manage to establish organic bonds with the public and remained mainly as an elitist initiative supported by middle-classes. In any case, constrained by the extraordinarily unfavourable socioeconomic circumstances of the period, the harsh hostility of the central government, the reactions of the business circles and the inter-partisan conflicts, the actual impact of the movement on the political traditions of the country could have been only inconsequential. Even if all these factors had been different, the military intervention of 1980 would not actually allow the furtherance of the movement.

\section{The eighties: Strengthening of local governments by the neo-liberal wave}

[31] If the rise of political violence was one aspect of the political crisis of the seventies, the severe economic problems represented the other aspect. The new economic orientations conceived 
Citation: Bayraktar, S. Ulaş (2007) 'Turkish municipalities: Reconsidering local democracy beyond administrative autonomy', European Journal of Turkish Studies, Articles, URL : http://www.ejts.org/document1103.html To quote a passage, use paragraph $(\S)$

as an answer to the economic crisis were determined by the famous decisions of January $24^{\text {th }}, 1980$ that inspired the economic transformation launched by the junta: the Turkish lira was immediately devaluated, restrictions on the foreign trade were abandoned, most of the state subventions were cancelled, interests were liberated and public incentives were introduced in order to encourage exportation and foreign investment. Last but not least, labour costs were indirectly reduced by forbidding workers' organisations. All these economic orientations were not indeed specific to the Turkish case. Since the worldwide economic crisis of the seventies, the neo-liberalism hat turned out to be the main economic reference in most countries. Additionally, international organisations such as IMF and World Bank had been imposing similar measures to all underdeveloped countries. In other words, the decisions of January $24^{\text {th }}$ and their rapid application by the junta were actually the local reflections of this global economic trend.

[32] The main objective of this neo-liberal trend was the lightening of administrative and financial burden of the state apparatus. In this perspective, local governments were considered as adequate instruments to reduce central responsibilities. As a result, for the first time, Turkish municipalities started to enjoy a gradual improvement of their financial resources and administrative competencies. As early as in 1981, the junta published two laws ( $n^{\circ} 2380$ and 2464 ) increasing the financial resources of local governments that were presided by appointed mayors. Yet, the actual progress would be realised between 1983 and 1987 by the Motherland Party (Anavatan PartisiANAP).

[33] ANAP obtained more than $45 \%$ of the votes despite all the generals' efforts -even direct support- on behalf of the party of an ex-general. Its leader, Turgut Özal claimed to represent liberal values of small-scale entrepreneurs, conservative priorities of religious groups and nationalist sentiments of the average (even radical) citizens. Yet, the main concern of Özal who was in fact the real author of the decisions of January $24^{\text {th }}$, was certainly the liberalisation of the markets along with the minimisation of the bureaucratic apparatus. Local implications of this neo-liberal orientation were immediate and could be followed through three main trends: decentralisation, de-socialisation and privatisation (Güler 1998: 185-194).

[34] Firstly, decentralisation implied changing the power and resource distribution scheme between the central government and municipalities in favour of the latter. With numerous laws passed by post-1980 governments, the financial resources of local governments were considerably 
Citation: Bayraktar, S. Ulaş (2007) 'Turkish municipalities: Reconsidering local democracy beyond administrative autonomy', European Journal of Turkish Studies, Articles, URL : http://www.ejts.org/document1103.html To quote a passage, use paragraph $(\S)$

improved to such an extent that municipal incomes were doubled between 1980 and 1986 (from $1.02 \%$ to $2.87 \%$ of their share of the GNP) and tripled between 1980 and 1993 (from 4.65\% to $13.84 \%$ of their share of national budget resources) (Güler 1990: 186). Yet this apparent increase in wealth did not actually mean real financial independence for local governments, as they did not control the allocated resources. The taxes that basically formed the source of these new resources were still decided on by central government, so dependence on Ankara was maintained.

[35] In addition to financial changes, local governments also experienced a functional evolution with the decentralisation of a number of administrative powers and responsibilities. For instance, the role of the municipalities in deciding and supervising local public investments was reinforced so that the share of the Bank of Departments in local investments fell from $70.2 \%$ to $14.9 \%$ between 1981 and 1995 (Güler 1998: 186). Municipalities also won the right to prepare and approve urban plans under Law No. 3030 which also introduced the status of metropolitan municipality to the local government system. However, as was the case with the improvement in the financial situation, functional transformation also failed to lead to the disappearance of centralist pressure. Central government continued to retain the right to intervene in local affairs when it thought necessary, such as when the social-democrats won local power in the major Turkish cities in 1989.

[36] Without changing the legal framework, central government thus managed to restrict local government's financial and administrative autonomy drastically. The political tension between the centre and local governments was back in the agenda. Yet this time, social democrat mayors of the period did not manage to propose or to develop an original political program on local governments and got caught between the administrative pressures from the centre and the everlasting demands of the local society not only in the domains of urban services but also in individual issues like employment, housing etc., with the result that they had to quit the local power after the elections of 1994. Nevertheless, the de facto 'go back and forth' with regards to the local autonomies remained in the agenda depending on the political parties in power of central and local governments.

[37] Secondly, the functional transformation of municipalities was also to be seen in the nature of the municipal services provided. In harmony with the neo-liberal trend, social and cultural services in areas such as health, education, housing, nutrition and heating, already very poor, were totally disregarded in order to de-socialize municipal duties. The direct intervention (e.g. subsidizing, organizing or facilitating ad hoc activities) and indirect intervention (e.g. market regulations or hygiene 
Citation: Bayraktar, S. Ulaş (2007) 'Turkish municipalities: Reconsidering local democracy beyond administrative autonomy', European Journal of Turkish Studies, Articles, URL : http://www.ejts.org/document1103.html

To quote a passage, use paragraph $(\S)$

control) of municipalities in these socio-cultural areas were thus discouraged in order to transfer these resources to more capital-friendly sectors. For this purpose, not only the municipal control of market prices and tariffs of elementary food and goods was abandoned, but also low-cost markets owned by municipalities were discouraged. Moreover, all through the eighties, the health services represented only $2.7 \%$ of the overall municipal costs while the proportion of social aid and educationculture-sports expenses were respectively $1.7 \%$ and $0.6 \%$ (Güler 1998: 188-189).

[38] The most neo-liberal aspect of the municipal transformation was the privatisation of some municipal services. To put it bluntly, the resources withdrawn from social areas and saved from operational costs were channelled to the private sector. So instead of providing the service itself, municipalities started purchasing the services from private companies or leaving the field wholly to private initiatives. Municipal services such as public transportation, urban hygiene, construction of infrastructure, parking, were thus henceforth handled by or in corporation with the private sector. Moreover, the structural incorporation of municipalities into free markets was also pursued by the multiplication of municipal enterprises. Founded as private companies, and hence free from the restrictions of administrative legal control, these municipal enterprises also sidestepped any kind of public control. In fact, even market forces were unable to influence these bodies since they generally enjoyed a monopoly position in their field. New municipal companies with immense capitals on the distribution of water, gas or public transportation (e.g. ISKI, ASKI, IGDAŞ, IZULAŞ) were thus founded (Şengül 2001: 111).

[39] The global legal umbrella of this three-fold transformation of Turkish local government was the introduction of metropolitan municipalities in 1984 under Law No. 3030. By this new legislation, certainly the most significant since the municipal law of 1930, the government of the largest cities was reformed so as to be handled at two different municipal levels. While the old district-based municipalities were maintained, they lost considerable resources and powers; a metropolitan municipality was introduced above these district governments, initially in the three largest cities, Istanbul, Ankara and Izmir. With the metropolitan municipalities in place, local democracy, already fragile, was further weakened, since the provinces started to suffer from the control and pressure of the metropolitan government in addition to that of the central government. Moreover, some aspects of the way it was organised weakened the democratic functioning of municipalities. For example, there were no elected members in the executive committees (encümen) 
Citation: Bayraktar, S. Ulaş (2007) 'Turkish municipalities: Reconsidering local democracy beyond administrative autonomy', European Journal of Turkish Studies, Articles, URL : http://www.ejts.org/document1103.html

To quote a passage, use paragraph $(\S)$

of metropolitan governments; they consisted solely of the chairmen of administrative departments (Eliçin-Arıkan 1997).

\section{Democratic deficiencies despite decentralisation}

[40] The municipal law of 1930 that was in force for three-quarters of a century until quite recently was continuously criticized for sidestepping the democratic development of Turkish local government by rendering it dependent on central resources and decisions. Under strict administrative tutelage of the central government, restricted functionally with basic public service delivery and financially constrained, local autonomy of municipalities have been the main item of discussion on Turkish local democracy. Yet, the picture seems to be inversed by the eighties; even the actual intention was not improving the quality of local democracy, all of these three dimensions underwent through very significant changes with the respective reforms of the municipal framework. So, in a theoretical perspective the main problems of Turkish local democracy should have been resolved by these legal and political changes of the 1980s.

[41] It is certainly true that Turkish municipalities were financially and administratively strengthened by all these legal changes in the eighties. But it is not so easy to claim that this enhancement of resources and powers contributed to the democratisation of local politics. On the contrary, the withdrawal of centralist pressures from the local political scene was accompanied with the multiplication of interventions from private interest groups. Since public transparency and accountability were not among the major issues of the legal amendments of the eighties, adequate local checks and balances were not established to replace the abandoned administrative tutelage. Attracted by the growing rent related to the urban land and/or services controlled by local governments, municipalities started representing very rich resources of rapid and easy enrichment for investors and entrepreneurs. Not capable or willing to resist to such illegitimate endeavours, mayors found themselves in the heart of private and usually unfair interest relationships. Thus, stories of corruption multiplied throughout the country. So to say, after being long dominated by central government, local politics was henceforth determined by usually illegitimate and even illegal networks of private interests 8 .

8 For a demonstration of the development of private interest networks in a Turkish city, see Bayraktar 2006: 351-358. 
[42] With the objective of demonstrating the ongoing democratic deficiencies of the municipal system in the post-1980 period, in the following section, I will highlight three different dimensions of local politics with direct reference to three main principles of democracy, namely separation of power; representation and participation. I will argue the need of re-defining local democracy by including these political elements in the conceptualisation.

\section{Mayors: Problem of power relations}

[43] The post-1980 Turkish local governments resemble a lot to the presidential system at the national scale with a very powerful mayor at the centre of municipal system. Already enjoying a significant influence since the amendment on direct election of mayors in 1963, their political power grew as centralist restrictions and pressures gradually eased. Particularly with the status of metropolitan municipality, mayors obtained considerable financial and administrative power as well as a superior status vis-à-vis the municipal councils.

[44] Municipal councils de jure deliberate and approve very important issues such as the budget, annual financial report, municipal activity plans, urban plan changes, debts and use of municipal properties. Despite these important functions, councils appear quite vulnerable vis-à-vis mayors for a couple reasons. First of all, mayors are also the presidents of the council which prevents us to speak of a veritable separation of powers at the local level. As a matter of fact, it is the mayor who determines the agenda of the council and supervises the meeting sessions. Moreover, in case of parity in a decision, it is the preference of the mayor that counts. In any case, the mayor disposes a right of veto to the decisions of the council on juridical pretexts ${ }^{9}$. Therefore, the decisive body of Turkish municipalities appears to be significantly powerless vis-à-vis mayors.

[45] The only veritable mechanism of control that municipal councils dispose is the approval of mayor's annual activity report. If the report is rejected by the three-fourth of the council, the mayor is considered insufficient and with the Council of State's approval, the mayor is dismissed from his/her functions. Yet, this legal mechanism of control is very hardly used and there has been almost no example of such a dismissal of mayor by the council's vote (Azaklı and Özgür, 2005: 311).

\footnotetext{
${ }^{9}$ If the council adopts the same resolution with a simple majority, the decision becomes valid. Nevertheless, the mayor may still take the issue to the administrative court.
} 
[46] Apart from such personal superiorities of mayors over councils, the former enjoy further influence through the executive committee that combines decisive, executive and consultative functions in the Turkish local governmental system. The committee that consisted of the appointed directors of the municipality until the recent reform ${ }^{10}$ can only deliberate the issues determined directly by the mayor, thus function under his/her direct influence. When the council is not at meeting, the committee can even decide upon the issues that normally fall under municipal council's competency thus replace the functions of the latter. That is to say, the mayor could easily bypass the council through the committee if ever the latter manages to oppose to the former, which is very rarely the case due to political reasons.

[47] In most of the cases, mayor's political party also holds the majority in the council bringing about a political uniformity between the executive and legislative organs of municipalities. One can yet ask whether being from the same party would ensure a permanent harmony. The answer is usually affirmative since, in principle, mayors should have disposed a veritable influence within the local party apparatus for being qualified as the candidate for mayoralty. If ever elected as the mayor ${ }^{11}$, s/he acquires much more power and influence within the party simply by reaching the summit of all local patronage and interest nexus ${ }^{12}$. Even those who formerly opposed to the mayor have to get along with him in order to assure their personal interests related to the new sources of urban rent determined mainly by the municipality. As a matter of fact, city is henceforth a valuable focus of investment and ground rent. New local practices such as drafting urban plans at the local level, privatizing municipal services and large-scale public investments ${ }^{13}$ rendered cities attractive centres of private investment. And mayors have the last word on such decisions of public investment and public service delivery and therefore stand at the heart of these networks of urban rent.

[48] This personal empowerment of mayors at the local level in the post-1980 period has been so remarkable that the political influence gained in local politics is henceforth transferred to the national political scene. A rapid list of such actors who managed to translate their local influence to a political power at the national level would be enough to illustrate this trend. The ex-mayor of the metropolitan municipality of Istanbul, Tayyip Erdoğan, is the prime minister of the country with an

\footnotetext{
10 In the new legislation, the numbers of elected and appointed members of the committee are equal.

11 The system used in the election of mayors is founded on the majority rule by single tour.

12 For an illustration of mayor's influence within the party, see again Bayraktar 2006: 211-219.

${ }^{13}$ The proportion of such large-scaled investments in the overall municipal costs reached to $30 \%$ in the early nineties and to $40 \%$ with the new millennium revealing the importance of such municipal activities (Yılmaz: 2004).
} 
Citation: Bayraktar, S. Ulaş (2007) 'Turkish municipalities: Reconsidering local democracy beyond administrative autonomy', European Journal of Turkish Studies, Articles, URL : http://www.ejts.org/document1103.html To quote a passage, use paragraph $(\S)$

overwhelming majority in the parliament; the actual mayor of Şişli, one of the richest municipalities of Istanbul, Mustafa Sarıgül, challenges the president of CHP; ex-mayor of Ankara, Murat Karayalçın, is the leader of the Social-democrat People's Party (SHP); the actual mayor of Ankara, Melih Gökçek, was considered as a possible leader of the islamist conservators; ex-mayor of the metropolitan municipality of Gaziantep, Celal Doğan, still pursues his project of founding a new socialist party, the ex-mayor of Istanbul, Ali Mufit Gürtuna launched a new political grouping (Turkuaz Hareketi), the deceased mayor of Izmir Ahmet Priştina was considered as one of the probable leaders of the Turkish social democrats, the mayor of Eskişehir Yılmaz Büyükersen is considered among the probable future leaders of the Turkish left. The list of local leaders who have become increasingly influential in their party or in national politics might be expanded beyond these names of extensive public visibility. More and more local leaders are henceforth considered among the principal political actors of the national political scene.

[49] With this overpowering status of mayors in the municipal framework, the executive branch has been thus over-strengthened at the expense of the local legislative as in a presidential system of national political systems. This leads naturally to a problematical distribution of power between local executive and legislative organs which has been illustrated by Kurtoğlu's empirical research on Keçiören. According to her findings (Kurtoğlu 2004: 316), only one third of the municipal councillors of the municipal council of Keçiören consider their position as an important status. Moreover, for some of these municipal councillors, the importance of the council is mainly related to their proper political carrier; it is considered as a springboard for future political ascension ${ }^{14}$.

[50] So to say, since the eighties, mayors have been the main power holders of the cities. They turned out to be very powerful local patrons enjoying an uncontrollable influence in the determination of local policies and on decisions related to the distribution of urban rent. The substitution of centralist pressures and restrictions by the personal empowerment of mayors did not thus represent a significant democratic development since the people remained as distant to government processes as before. In other words, the peripheries that had long suffered from centralist pressures created their own hegemonic centres in the personalities of mayors. To put it differently, Turkish local governmental system has evolved towards a new form that can be compared with the presidential systems of national politics. Directly elected by the citizens and enjoying more

\footnotetext{
${ }^{14}$ Erder observes the same feature among the councilors of Ümraniye (Erder 1996: 124-127).
} 
Citation: Bayraktar, S. Ulaş (2007) 'Turkish municipalities: Reconsidering local democracy beyond administrative autonomy', European Journal of Turkish Studies, Articles, URL : http://www.ejts.org/document1103.html

To quote a passage, use paragraph $(\S)$

and more administrative and financial competencies and resources as well as political capital, mayors represent henceforth the main power-holder within local politics. This uneven distribution of power within local politics is certainly problematic since the hegemonic position of the mayor contradicts with the democratic role of other political institutions and citizens.

\section{Municipal councils: problem of representation}

[51] The weakness of municipal councils vis-à-vis mayors is obviously inconsistent with a democratic structuring of local politics. Nevertheless, it is equally difficult to argue that the system would become more representative with a more fair relationship between the mayor and the council simply because the council itself also suffers from problems of representation.

[52] This problem of representativity is because the councils have been traditionally dominated by specific socioeconomic and/or ethnic groups. For example, Erder and İncioğlu who analysed the composition of the municipal council of Istanbul between 1977 and 2004 observe that the council of 1977 was marked by the weight of merchants and small entrepreneurs (Table 1). The significant changes in the municipal practices during the eighties had its direct reflections on the municipal council; entrepreneurs who were extremely interested in the investment projects of the municipality obtained and kept their influence within the respective councils (Erder, İncioğlu 2004: 542-551). As a matter of fact, Doğan (2007: 155) observes the same feature within the municipal councils of Kayseri where entrepreneurs (particularly construction contractors) appear to be most present professional group.

Table 1. Professional activities of the municipal councillors of Istanbul between 1977- 2004

\begin{tabular}{|l|l|l|l|l|l|l|}
\hline Professional domain of councillors & $\mathbf{1 9 7 7}$ & $\mathbf{1 9 8 4}$ & $\mathbf{1 9 8 9}$ & $\mathbf{1 9 9 4}$ & $\mathbf{1 9 9 9}$ & $\mathbf{2 0 0 4}$ \\
\hline Construction, production, commerce & $\mathbf{2 8 . 6 \%}$ & $60.8 \%$ & $27.1 \%$ & $42.6 \%$ & $41.6 \%$ & $28 \%$ \\
\hline Independent & $27.1 \%$ & $20.6 \%$ & $35.0 \%$ & $36.2 \%$ & $32.2 \%$ & $49 \%$ \\
\hline Public or private employee & $3.8 \%$ & $4.9 \%$ & $6.4 \%$ & $8.1 \%$ & $16.3 \%$ & $19 \%$ \\
\hline Merchant & $15.8 \%$ & $2.0 \%$ & $15.8 \%$ & $5.1 \%$ & $3.5 \%$ & $1 \%$ \\
\hline Labourer, unionist & $4.5 \%$ & $0.9 \%$ & $6.4 \%$ & $2.5 \%$ & $1.0 \%$ & 0 \\
\hline Retired, housewife & $7.5 \%$ & $10.8 \%$ & $8.6 \%$ & $2.5 \%$ & $3.4 \%$ & 0 \\
\hline Unknown & $12.8 \%$ & 0 & $0.7 \%$ & $3.0 \%$ & $2.0 \%$ & $1 \%$ \\
\hline
\end{tabular}

Source: Erder, İncioğlu 2004: 541. 
Citation: Bayraktar, S. Ulaş (2007) 'Turkish municipalities: Reconsidering local democracy beyond administrative autonomy', European Journal of Turkish Studies, Articles, URL : http://www.ejts.org/document1103.html

To quote a passage, use paragraph $(\S)$

[53] Apart from the over-representation of certain professional groups, the representativity of Turkish municipal councils has been also weakened due to the overwhelming influence of townsmen (hemşehri) networks founded upon sentiments of belonging to a specific locality or a culture. Developed informally with the objective of facilitating cooperation and solidarity among the emigrants of the same locality, these networks played a major role during the settlement of the new inhabitants in large cities. Although first appeared as passive communities following the traditional urban political elite, these networks started recruiting their own political elites once they resolved their immediate urban needs such as housing and employment and thus reached to a relative urban welfare. As a matter of fact, $75 \%$ of municipal councillors interviewed by Kurtoğlu (2004: 305) acknowledge the importance of the support of their townsmen in their election. As presented in Table 2, Erder and İncioglu's analysis also confirms this particularity of Turkish local politics. The regions from where newcomers of Istanbul have mainly emigrated have been significantly over-represented in the Council. In addition to the sustaining weight of those from the Black Sea Region, the Eastern and South-eastern and to a lesser extent Central Anatolia gradually acquire an actual power within the council. On the other hand, we see a stable decrease of the presence of those who were born in Istanbul until 200415 .

Table 2. Regional origin of the municipal councillors of Istanbul between 1977- 2004

\begin{tabular}{|l|l|l|l|l|l|l|}
\hline Regional origin of councillors & $\mathbf{1 9 7 7}$ & $\mathbf{1 9 8 4}$ & $\mathbf{1 9 8 9}$ & $\mathbf{1 9 9 4}$ & $\mathbf{1 9 9 9}$ & $\mathbf{2 0 0 4}$ \\
\hline Istanbul & $36.1 \%$ & $\mathbf{2 1 . 6 \%}$ & $\mathbf{1 7 . 1 \%}$ & $\mathbf{1 8 . 3 \%}$ & $\mathbf{1 4 . 3 \%}$ & $\mathbf{2 3 \%}$ \\
\hline Black Sea & $33.1 \%$ & $27.5 \%$ & $24.3 \%$ & $29.4 \%$ & $37.0 \%$ & $31 \%$ \\
\hline East and Southeast & $\mathbf{9 \%}$ & $15.7 \%$ & $27.9 \%$ & $27.0 \%$ & $21.3 \%$ & $20 \%$ \\
\hline Marmara & $4.5 \%$ & $\mathbf{7 . 8 \%}$ & $9.3 \%$ & $6.6 \%$ & $6.5 \%$ & $3 \%$ \\
\hline Central Anatolia & $6.8 \%$ & $11.8 \%$ & $15.7 \%$ & $13.7 \%$ & $14.4 \%$ & $12 \%$ \\
\hline Other regions & $4.5 \%$ & $8.8 \%$ & $2.9 \%$ & $3.0 \%$ & $4.5 \%$ & - \\
\hline Other countries & $3 \%$ & $6.7 \%$ & $2.1 \%$ & $2.0 \%$ & $2.0 \%$ & $2 \%$ \\
\hline Unknown & $3 \%$ & - & - & - & - & $2 \%$ \\
\hline
\end{tabular}

Source: Erder, İncioğlu 2004: 541.

[54] It is of course impossible to limit the level of representation to professional or kinship bonds of councillors who can also defend the interests of other fellow citizens. But, the specific

15 The return of those who were born in Istanbul to the municipal council of 2004 would not necessarily represent the weakening of sentiments of regional appurtenance. The townsmenship has been also reproduced among the new generations who are born and grown up in Istanbul. In fact, this is one of the main objectives of townsmen associations (see Bayraktar 2003). 
Citation: Bayraktar, S. Ulaş (2007) 'Turkish municipalities: Reconsidering local democracy beyond administrative autonomy', European Journal of Turkish Studies, Articles, URL : http://www.ejts.org/document1103.html

To quote a passage, use paragraph $(\S)$

interest of certain socio-professional groups in municipal councils can be neither just by chance nor without any political consequence. When thought together with the clientelist character of Turkish politics that I shall discuss below, I can note a more privileged representation of certain socioprofessional groups in local politics as another problematical dimension of Turkish local democracy.

[55] The representational weakness of municipal councils is not only due to the overrepresentation of certain groups, but also because of the electoral system based on d'Hont method with a local threshold of $10 \%$ in a single tour. Thus, already with highest thresholds both in local and national politics, relatively smaller parties that can not receive the support of one tenth of voters are totally isolated from the council. Moreover, the d'Hont method is known to render the stronger parties more advantaged in the seat allocation accounts. Last but not least, the contingent ${ }^{16}$ seats reserved for the party that obtains the largest percent of votes enhances the power of the largest party in the council. As a result, even if the electoral system of municipal councils is considered to be proportional, these privileges that the stronger parties dispose render the system quite unfair for smaller parties and thus for all voters that they represent. Yet, the situation for the voters of larger parties is not neither exemplary since the candidates are not nominally presented on the ballot preventing preferential voting. Therefore, most of the voters make their choices without even having any idea on whom they are actually electing as a councillor. The lists prepared most often by the party apparatus behind closed doors respecting the internal power balances instead of representative or professional qualities, aggravates the problem of democratic representation of municipal councils. As a matter of fact, a national survey realised with over 1220 citizens from all over the country, reveals that only $5 \%$ of the population believes that municipal councils represent their interests (Adaman, Çarkoğlu, Şenatalar, 2005: 41) 17.

[56] In addition to their relative politico-administrative weakness vis-à-vis mayors, municipal councils have not thus appeared as institutions of democratic political representation of the general public interest due to both the over-representation of either specific professions or townsmen groups as well as the problems of representation directly related to the electoral system. In other words, in

\footnotetext{
16 The number of contingent councilors can be up to 6 representing the $10 \%$ of whole council.

17 Mayors enjoy a much greater power of representation in citizens' eyes; $40 \%$ of the interviewees declare their confidence towards mayors. Yet, it should be noted that this confidence is recently gained since according to the results of the same survey in 1999 , only $23 \%$ of the interviewees seemed to trust the mayors. For the councils, the change is quite negligible with a slight fall of $1 \%$ (loc. cit.).
} 
Citation: Bayraktar, S. Ulaş (2007) 'Turkish municipalities: Reconsidering local democracy beyond administrative autonomy', European Journal of Turkish Studies, Articles, URL : http://www.ejts.org/document1103.html

To quote a passage, use paragraph $(\S)$

the traditional municipal framework, municipal councils have been far from carrying out a democratic function within local politics.

[57] Very interestingly, whereas the main representative institution of municipal system fails to represent adequately the general public interest due to the accentuated influence of some professional and communitarian groups, another set of professional organisations can be considered as the main spokesmen of general public problems and interests. As a matter of fact, professional chambers ${ }^{18}$, especially those of engineers, dentists, pharmacists, financial consultants, independent accountants, doctors, veterinarians as well as the Bar appear as non-negligible political actors in national and local politics. Assembling most of the 'white-collars' of a city and enjoying a general legitimacy with their technical expertise on the quasi-totality of the socioeconomic life, from industrialisation to accountancy, from public health to judicial system, from environmental protection to urbanisation etc. the political position adopted by these chambers is generally respected within the public opinion.

[58] This general respect and confidence towards these professional chambers render them very influential in local politics since they can easily incite very important collective mobilisations in the cities. Especially, engineers that have built up also a national union under the name of Union of Turkish Chambers of Engineers and Architects (TMMOB - Türk Mühendis ve Mimar Odalar Birliği ${ }^{19}$ ) and represented by a Provincial Council of Coordination (IKK, II Koordinasyon Kurulu) in cities have been present in most of the social movements on behalf of public interest.

[59] Despite this important influence, the role of these chambers in local politics has not been yet analysed. Therefore, a new understanding of local democracy that would cover the issues of political representation should also deal with the functions and status of professional chambers in local politics.

\footnotetext{
18 Professional chambers are organizations to which all those who exercise a specific profession have to adhere enjoy a public identity and considered as quasi-public institutions.

19 Founded in 1954, the Union regroups 23 professional chambers and 280,263 engineers and architects (http://www.tmmob.org.tr/cr/degisiklik/2.8.\%20uye\%20sayilari.xls, last consultation June 22nd, 2006). The Union has been traditionally identified with leftist tendencies; a characteristics that the Union has always assumed.
} 


\section{Citizens: Problem of participation}

[60] The great absent in this transformation of municipal system and thus local politics is citizens' influence within local public affairs although the $13^{\text {th }}$ article of the Law 1580 on municipalities had clearly mentioned the right of fellow-citizens to participate to local governments ${ }^{20}$. But this right of fellow-citizenship unfortunately remained on paper without leading to any opportunities or instruments of citizens' participation in local politics.

[61] Evolving on the one hand towards omnipotent mayors and dominated councils on the other, participation of citizens to municipal decision-making processes remained quite restricted. In the absence of adequate organs or practices, citizens have been deprived from democratic means of active involvement in local politics. Instead, hierarchical patronage networks have developed as the main nexus of local and national politics.

[62] Already rich in factional oppositions and alliances based on kinship, ethnic, religious or community-oriented cleavages, Turkish social structure paved the way to the development of patronage relations working through vertical networks of leader-follower relationships (Sayarı, 1975, 123-125). As a consequence of the vulgarisation of clientelist relations, a political culture based on democratic organisation and collective mobilisation has not been generalised. Thus, deprived from formal instruments of active involvement in local politics and influenced by the traditional political culture identified with widespread patronage networks, citizens' participation remained restricted to personal endeavours in order to solve their specific and personal problems through the hierarchical patronage networks.

[63] What is problematic about these clientelist channels of political participation is that they all function through hierarchical or at least unequal power relationships rather than respecting democratic principles. Consequently, a citizen's chance to influence political affairs depends more on his/her social capital than the nature of his/her demand or need. Therefore, even for those who enjoy an easy access to municipal organs we can not speak of a veritable democratic representation since such channels of participation contradict with the principles of equity and equality

20 'Each citizen is the fellow-citizen of the locality where s/he is registered administratively. Fellow-citizens have the right of vote, being elected, and participation in municipal administration and of profiting from the permanent aids of the local government.' 
[64] This characteristic of Turkish local politics represents another deficiency of local democracy that has been neglected by the traditional reading of the notion in a restricted perspective of local autonomy. Therefore, the quality and the scope of civic participation in local politics and decision-making processes should be carefully examined in order to re-define local democracy in more political terms.

[65] In such an inquiry, local branches of political parties would most probably appear as one of the main study objects. Very interestingly, to our knowledge, except for some exceptional studies (Güneş-Ayata 1992; Schüler 1999), local political organisations have not been specifically analysed. Yet, it is undeniable that they dispose non-negligible political influence over central as well as local governments as the actual junction of clientelist relationships at the local level. Therefore, in order to be able to reach to a new and more comprehensive understanding of local democracy, the role that local political party organisations play in local politics must be (re-) considered. Their control over patronage networks thus on the nature of political endeavours of citizens must be discovered to adequately conceptualise local democracy that includes also the dimension of citizens' political participation.

\section{Conclusion: local democracy beyond municipal autonomy}

[66] The municipal law of 1930 that was in force for three-quarters of a century until quite recently was continuously criticized for sidestepping the democratic development of Turkish local government by rendering it dependent on central resources and decisions. Yet, as I have argued, the municipal geography was very significantly transformed even though the legal framework was mainly maintained. In any case, the de facto transformation of the local governmental system does not seem to solve the question of Turkish local democracy since the improvement of administrative and financial autonomy as well as functional capabilities of local governments seemed to be coupled with the overwhelming influence of powerful mayors. The competencies and resources transferred to the local level were not distributed equitably among different organs of the local governmental system. Thus, central government's overseeing and control of municipal functions and resources seems to be being gradually substituted - though not entirely - by the hegemonic empowerment of local executives in the personality of mayors. Moreover, municipal councils that were left subjected to local executives in the absence of adequate political power were actually identified by the influence of 
Citation: Bayraktar, S. Ulaş (2007) 'Turkish municipalities: Reconsidering local democracy beyond administrative autonomy', European Journal of Turkish Studies, Articles, URL : http://www.ejts.org/document1103.html

To quote a passage, use paragraph $(\S)$

certain professional groups or of townsmen networks, they do not actually appear as appropriate institutions of democratic representation. Last but not least, the dissociation of citizens from local politics has continued despite these important changes in the municipal system.

[67] In the light of these observations, I would argue that the evolution of the Turkish municipal system since the eighties improved the state of local autonomy without representing an actual impact on local democracy. Central government's overseeing and control of municipal functions and resources seems to be being gradually substituted - though not entirely - by the hegemonic empowerment of local executives in the personality of mayors. Put simply, the 'centreperiphery' dichotomy has been replaced by a problematic scenario of 'centres in the periphery'.

[68] Meanwhile, after dozens of draft bills, lengthy debates in specific commissions and parliamentary sessions, the AKP (Party of Justice and Development) government reformed the law on local governments in July 2005. The new legislation enhances the local autonomy by delegating more competencies and resources and lightening the administrative tutelage. It is also true that the status of municipal councils has been relatively improved by new legal changes such as monthly meetings, the introduction of the strategic plans providing concrete references for the control of mayors by municipal councils, the equal representation of elected councillors in the executive committee as well as the creation of commissions of expertise and control. Moreover, the new law emphasises also the importance of civic participation by introducing new mechanisms and practices (city councils, strategic plans, growing influence of the muhtar and explicit emphasise of the participation of experts to the specific municipal commissions). But the fate of the 'rights of fellowcitizens in the former legislation makes us sceptical about the actual practice. As a matter of fact, the concern for more a democratic municipal structure seems to be quite shadowed by efforts for more efficient, effective and economic local governments respecting the neo-liberal priorities and principles ${ }^{21}$.

[69] It is still too early to comment on the present state of local politics that will be without any doubt significantly affected by the recent reforms. The need to include more political elements in future analysis on local democracy is the main argument of this paper rather founded on the

\footnotetext{
21 It is quite interesting to note that the word 'democracy' or 'democratic' is pronounced in none of the new laws on local governments (on municipalities, metropolitan municipalities or provincial governments) whereas the famous three E's of neo-liberal agenda (economy, efficiency and effectiveness) are found in all three legislation. For a discussion on the participatory character of the new legislation, see Bayraktar 2007.
} 
Citation: Bayraktar, S. Ulaş (2007) 'Turkish municipalities: Reconsidering local democracy beyond administrative autonomy', European Journal of Turkish Studies, Articles, URL : http://www.ejts.org/document1103.html

To quote a passage, use paragraph (§)

preceding experiences of Turkish municipalism. In other words, I claim that all discussions on local democracy without carefully considering the state of power distribution as well as the status of citizens, professional chambers and local party organisations would be (and has been) oversimplistic. 


\section{References}

Adaman, Fikret; Çarkoğlu, Ali; Şenatalar, Burhan (2005) Toplumun kamu yönetimine, kamu hizmetlerine ve reforma bakışı, Istanbul, Tesev yay.

Ahmad, Feroz (1993) The Making of Modern Turkey, London and New York, Routledge.

Altaban, Özcan (1990) '1960-1973 dönemi belediyeciliğine genel bakış (A general overview of municipalism between 1960-1973)' in Türk belediyeciliğinde 60 yıl bildiri metinleri [60 years in Turkish municipalism conference proceedings], Ankara, Metropol İmar A.S. and IULA-EMME, pp. 317-325.

Aytaç, Fethi (1990) 'Belediye Kanunu'nun oluşumu, uygulanması ve değişiklikler [The determination, application and changes of the municipal law]' in Türk belediyeciliğinde 60 yıl bildiri metinleri [60 years in Turkish municipalism conference proceedings], Ankara, Metropol İmar A.S. and IULAEMME, pp. 86-106.

Azaklı, Sedat; Özgür, Hüseyin (2005) 'Belediye organları ve organlar arası ilişkiler: Başkan, meclis ve encümen [Municipal organs and the relations between the organs: Mayor, council and committee]' in Özgur, Hüseyin; Kösecik, Muhammet (eds.), Yerel Yönetimler Üzerine Güncel Yazılar-I [Contemporary writings on local governments-I], Ankara, Nobel Yay., pp. 297-319.

Bayraktar, S. Ulaş (2003) 'Formelleşen Hemşehri Dayanışma Ağları: İstanbul'daki Hemşehri Dernekleri [Formalised solidarity networks of fellow townsmen: Hometown associations in Istanbul]', Toplumbilim, 17, pp. 107-119.

Bayraktar, S. Ulaş (2006) Local Participatory Democracy: The Local Agenda 21 Project in Turkish Cities, unpublished PhD Thesis, Institut d'Etudes Politiques de Paris, http://ecoledoctorale.sciencespo.fr/theses/theses en ligne/bayraktar scpo 2006/bayraktar scpo 2006.htm, last consultation August 5th, 2007.

Bayraktar, S. Ulaş (2007) 'Relations between local governments and non-governmental organisations in contemporary Turkey', paper presented at the XVIII. Symposium of Civil Society, Istanbul, 22-23 June 2007.

Doğan, Ali Ekber (2007) Eğreti Kamusallık, Istanbul, Illetişim yay.

Eliçin-Arıkan, Yeşeren (1997) 'Municipalités métropolitaines et municipalités d'arrondissement en Turquie', CEMOTI, 24, pp. 71-104.

Erder, Sema (1996) İstanbul'a bir kent kondu: Ümraniye, İstanbul, Illetişim yay.

Erder, Sema; İncioğlu, Nihal (2004) 'Yerel politikanin yükselişi: İstanbul Büyükşsehir Deneyimi 19842004' in IIlkin, Selim et al. (ed.), IIhan Tekeli için armağan yazılar, İstanbul, Tarih Vakfı Yurt yay.

Geray, Cevat (1990) 'Belediyelerin hizli kentleşmeye yenik düştüğü dönem (1945-1960) [The period during which the municipalities were defeated by the rapid urbanisation]' in Türk belediyeciliğinde 60 yıl bildiri metinleri [60 years in Turkish municipalism conference proceedings], Ankara, Metropol İmar A.S. and IULA-EMME, pp. 217-224.

Görmez, Kemal (1997) Yerel Demokrasi ve Türkiye, Ankara, Cadi yay. 
Citation: Bayraktar, S. Ulaş (2007) 'Turkish municipalities: Reconsidering local democracy beyond administrative autonomy', European Journal of Turkish Studies, Articles, URL : http://www.ejts.org/document1103.html To quote a passage, use paragraph $(\S)$

Güler, Birgül Ayman (1998) Yerel Yönetimler: Liberal açıklamalara eleştirel yaklaşım [Local governments: Critical approach to liberal explanations], Ankara, TODAIE.

Güneş-Ayata, Ayşe (1992) CHP (Örgüt ve ideoloji), Ankara, Gündoğan.

İncioğlu, Nihal (2002) 'Local elections and electoral behaviour' in Sayarı, Sabri; Esmer, Yılmaz (ed.), Politics, parties, and elections in Turkey, London, Lynne Rienner Publishers, pp. 73-90.

Karpat, Kemal H. (1991) 'The Republican People's Party 1923-1945' in Heper, Metin; Landau, J. M. (ed.), Political Parties and Democracy in Turkey, London, I. B. Tauris Co Ltd Publishers, pp. 42-64.

Kurtoğlu, Ayça (2004) Hemşehrilik ve şehirde siyaset, Istanbul, Illetişim yay.

Mumcu, Ceyhan; Ünlü, Halil (1990) 'Idare hukuku açısından belediye kanunu [Municipal law in the administrative code perspective]' in Türk belediyeciliğinde 60 yıl bildiri metinleri [60 years in Turkish municipalism conference proceedings], Ankara, Metropol İmar A.S. and IULA-EMME, pp. 107-118.

Öner, Şerif (2005) 'Katıımcı demokrasi açısından belediye kanunu [The municipal law from the perspective of participatory democracy]' in Özgur, Hüseyin; Kösecik, Muhammet (ed.), Yerel Yönetimler Üzerine Güncel Yazılar-I [Contemporary writings on local governments-I], Ankara, Nobel Yay., pp. 57-87.

Özbudun, Ergun (1995) 'Türkiye'de devlet seçkinleri ve demokratik siyasal kultur' [State elites and democratic political culture in Turkey]' in Özbudun, Ergun et al. (ed.), Türkiye'de Demokratik Siyasal Kültür [Democratic political culture in Turkey], Ankara, Türk Demokrasi Vakfi yay., pp. 1-42.

Rao, Nirmala; Berg, Rikke (eds.). Transforming local political leadership, London, Palgrave Macmillan, 2006.

Rustow, Dankwart A. (1991) 'Political parties in Turkey: An overview' in Heper, Metin; Landau, J. M. (eds.), Political Parties and Democracy in Turkey, London, I. B. Tauris Co Ltd Publishers.

Sayarı, Sabri (1975) 'Some notes on the beginnings of mass political participation' in Akarlı, Engin D.; Ben-Dor, Gabriel (eds.), Political participation in Turkey: historical background and present problems, Istanbul, Boğaziçi University Pub., pp. 121-133.

Schüler, Harald (1999) Türkiye'de sosyal demokrasi: Particilik, hemsehrilik, Alevilik, İstanbul, İletisim yay.

Şengül, H. Tarik (2001) 'Türkiye'de kentleşmenin izlediği yol üzerine: bir dönemleme girişimi [On the path that the urbanisation has followed in Turkey: An attempt of periodisation]' in Kentsel çeliski ve siyaset [Urban contradiction and politics], İstanbul, Demokrasi Kitaplığı, pp. 61-94.

Turan, Ilter (1993) 'Politicians: Populist Democracy' in Heper, Metin et al. (ed.), Turkey and the West: Changing Political and Cultural Identities, London, I. B. Tauris Co Ltd Publishers.

Yüksel, Fatih (2005) 'Yerel özerklik kavramı üzerine bir inceleme [An analysis on the notion of local autonomy]' in Özgur, Hüseyin; Kösecik, Muhammet (eds.), Yerel Yönetimler Üzerine Güncel Yazılar-I [Contemporary writings on local governments-I], Ankara, Nobel Yay., pp. 275-296. 